Ilija Ž. Mikić

Archaeological Institute, Belgrade

mikicilija82@gmail.com

UDK 902.6:572(497.11)"04/14"

904:726.8(497.11)"04/14"

Original research article

Nina M. Korać

Archaeological Institute, Belgrade

Received: April 08, 2010

Accepted: August 02, 2010

\title{
MEDIAEVAL CEMETERIES BY THE ZAVOJSKO LAKE NEAR PIROT - PALEODEMOGRAPHIC AND PALEOPATOLOGIC ANALYSIS
}

\begin{abstract}
During archaeological excavation in 1988, conducted next to the St. Nikola's monastery, 28 skeletons were discovered. In the same year, next to the church of Holy Resurrection (Svetog Vaznesenja), 157 individual skelteons were excavated. Within their anthropological study, paleodemographic, as well as paleo-pathologic analyses were undertaken. The results gained were very indicative for the Middle Age, actually for cemeteries connected to sacral objects and contrary to those placed within urban centres. Their presentation is the main topic of this interdisciplinary paper.
\end{abstract}

Key WORDS: BiophysicAl ANTHROPOlOGY, ARCHAEOLOGY, SEX, AGE, LIFE LENGTH,

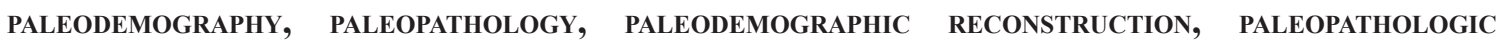
INTERPRETATION.

\section{INTRODUCTION}

The Zavojsko lake is situated some $17 \mathrm{~km}$ to the north from Pirot. It was named after the Zavoj village, which was flooded after the natural errosion of the Visočica River formed a natural dam. After that, a man-made dam was built upon the natural one. The water from the lake is lead through tunnels and used for the "Pirot" water power-plant. The lake itself is $17 \mathrm{~km}$ long and its greatest depth measueres $70 \mathrm{~m}$. Today, it also represents a touristic attraction.
During the late eighties of 20th century, archaeological survey of the nearby area was undertaken, because, due to the relief changes caused by accumulatied water, some parts were flooded both modern settlements and ancient archaeological sites. Parallel to archaeological excavations, anthropological studies were made of skeletons discovered in the villages of Zavoj, Velika and Mala Lukanja. ${ }^{1}$

1 Anthropological documentation used for this publication was handed to the authors by the retired professor of anthropology of the Philosophical Faculty in Belgrade, $\check{Z}$. Mikić, for which we express our gratitude.

* The article results from the project: Viminacium, Roman city and military legion camp - research of material and non material of inhabitants by using the modern technologies of remote detection, geophysics, GIS, digitalisation and 3D visualisation (no 47018), funded by Ministry of Education and Science of the Republic of Serbia. 


\section{ARCHAEOLOGICAL CONTEXT}

Archaeological research in 1988 at the medieval sites in the villages of Zavoj, Velika Lukanja and Mala Lukanja were conducted by Predrag Pejić M.A., custodian-archaeologyst of the Ponišavlje Museum in Pirot. ${ }^{2}$ In the catalogue of the permanent exibition about these excavations, printed in 1991, he writes that there were three medieval cemeteries with inhumations burried in rows. The oldest is the one next to the St. Nikola's monastery, in the village of Mala Lukanja. According to the grave goods from these graves, the cemetery was dated into the period from 12th to 14th century. The excavated area measured $660 \mathrm{~m}^{2}$, which is just a smaller part of the cemetery. Archaeological excavations revealed 28 graves, i.e. 28 individual skeletons which were anthropologicaly studied.

Within the area of the former Velika Lukanja village, only a smaller part of a medieval cemetery $\left(55 \mathrm{~m}^{2}\right)$ was unearthed. Seven individual graves were excavated, which were dated from 15 th to 17 th century according to grave goods found within them. Still, apart from being less numerous, this osteological material was also poorly preserved and therefore not included into this study.

In the Zavoj village, which was abandoned during the sixties of 20th century, there was a church of Holy Resurrection (Svetog Vaznesenja) with a necropolis which was in use during a long period of time from 15th all the way to 19th or even to the middle of 20th century. It is actually a graveyard next to the sacral object which, in time, spread further away from the church and closer to the village. Some $200 \mathrm{~m}^{2}$ of the oldest part of the cemetery next to the church were archaeologically examined. Here, 137 graves were unearthed, but also three graves within the church, which should

2 We also express our gratitude to P. Pejić, M.A. for the handed archaeological data which were quoted in this paper. be the oldest ones. Since the younger part of this cemetery was not excavated, one should consider that the human osteological material studied could belong to the period between 15th and 17th century. Still, it should be noticed that this cemetery could not be completely examined.

\section{MATERIAL}

The first conclusion about the anthropological material from the St. Nikola's monastery from the village of Mala Lukanja and from the church of Svetog Vaznesenja in Zavoj, is their poor state of preservation. Due to the poor state of conservation and small number of samples, the osteological material from Velika Lukanja was not included into this interdisciplinary analysis. Generally, we had 28 individual skeletons from the first medieval necropolis (St. Nikola's monastery) and 140 individual skeletons from the second cemetery (the church of Svetog Vaznesenja) were at our disposal. After the anthropological analysis conducted in 1988, according to Serbian orthodox customs, all of the bones were burried in a common grave on a new location, followed with an adequate church ritual, and therefore it was not possible to deposit them or observe or photograph them afterwards. Apart from that, in the meantime, these mediaeval cemeteries were mentioned in the catalogue named above, but in the anthropological sense, these osteological finds are published here for the first time.

\section{METHOD}

For the needs of both paleodemographic and paleopathological analyses it is first necessary to determine the gender and individual age of every skeleton. On the here presented skeletons, gender was determined according to 21 morphological elements on skull and post-cranial skele- 
ton. These include the following gender-morphological elements: 1. Tuber frontale et parietale, 2. Glabela-arcus supercilialis, 3. Processus mastovdeus, 4. Protuberantia occipitalis externa, 5. Squama occipitalis, 6. Sharpness of orbital bows, 7. Arcus zygomaticus, 8. Pacies malaris, 9. Corpus mandibulae, 10. Trigonum mentale, 11. Angulus mandibulae, 12. Capitulum mandibulae, 13. Angulus pubis, 14. Pelvis maior, 15. Pelvis minor, 16. Foramen obturatum, 17. Incisura ischiadica maior, 18. Sacrum, 19. Caput femoris, 20. Linea asperae on femurs and 21. Clavicula (Ferembach, Schwidetzky, Stloukal 1979). With incompletely and poorly preserved skeletal remains, which made most of the here studied material, sex was determined only after the elements preserved. With completely destroyed adult skeletons, sex was determined only with certain possibility (also named within referrent tables).

For age of adolescents between 14-15 years, lists according to Kronfeld (Kronfeld 1954) were used. For the individual age between 14-15 and 21-23 years, diagrams were used according to Wolf-Heidegger (Wolf-Heidegger 1954). With adults, whose ossification processes of long bones and teeth growth were completed, age was determined according to a complex method based on the following elements: 1 . Obliteration degrees of skull sutturae, 2. Density degree of the spongiose mass within humerus' head, 3. Density degree of the spongiose mass within femur's head, 4. Relief surface of carliene simphyses and 5. Abrasion degree of molar teeth in both jaws (Ferembach, Schwidetzky, Stloukal 1980).

Within the complete anthropological study and according to R. Martin's methodological rules (Martin and Saller 1957, 429-518) twelve primary skull measurments were taken on the bones put at our disposal: 1. The utmost skull length, 8 . The utmost skull width, 9. The smallest forehead width, 17. The basion-bregma height, 20. The socalled ear-height of skulls, 45. Cheekbone width, 48. The height of the upper face part, 51. The width of eye holes, 52 . The height of eye holes, 54. The width of nasal openning, 55. The height of nasal openning and 66. The so-called angular width of mandibula. Out of these measurments and depending of the state of preservation, certain skull indexes can be calculated and categorized.

As certain tables in this paper point out, due to the poor state of preservation, detailed and numerous measurments of the long, post-cranial bones were not taken. According to the methodological rules of R. Martin (Martin and Saller 1957), only in a small number of cases the greatest femur length (F. 1) and the greatest humerus length (H. 1) was measured. Although less numerous, these measurments for both sexes made it posible to calculate individual height with the help of regression tables. These include the regression tables of E.Breitinger (Breitinger 1938) for male individuals and of H. Bach (Bach 1965) for female individuals, which correspond best to the European population of past times

For detecting paleopathological changes on bone tissues, jaws and teeth, and according to our experience, atlas of A. Lovrinčević and Ž. Mikić (Lovrinčević and Mikić 1989) are very useful, as well as an instruction book of E. Hošovski and Ž. Mikić (Hošovski and Mikić 1995). Publications by D. R. Brothwell (Brothwell 1965) and R. T. Steinbock (Steinbock 1976) also had to be consulted. Still, paleopathological observation could only be performed with a macroscopic method, because the whole study of the anthropological material was done in a filed laboratory and during 1988 , i.e. during the existence of the "Direction for building the Zavojsko lake dam".

An attempt to follow epigenetic elements according to the method published by A. C. Berry and R. J. Berry in 1967 (Berry and Berry 1967) did not result as it was expected, mostly due to the very poor state of preservation. Still, for the analyses planned for this mediaeval ostheological material this is not of utmost importance. 


\section{RESULTS}

From the cemetery of the St. Nikola's monastery, as the older of the two sites, 28 graves were excavated, which present only a smaller number of the total, since the monastery's cemetery could have not completely been investigated. As table 1 shows, the most of the grave contents were only determined according to their sex and age (for a good overview, archaological and anthropological numerations were introduced). As for sex, only the skeletons from the graves numerated as 15 and 27 were marked as probably male, i.e. probably female, due to the lack of preserved markers needed. Still, skeletons no. $14,23,24$ and 25 were in such a poor condition that their sex could have not been determined at all. It was only posible to determine that they belonged to adult individuals, from 20 years of age and upwards. In general, the excavated part of the necropolis included 11 male, 2 female and 11 skeletons of infants in the first life decade, as well as the mentioned four skeletons.

The age structure of the skeletons is only partly known. For infants it can also be said that most of them died in the first few years of their lives. For both of the female skeletons, as shown in table 1 , age was very difficult to determine. It was also difficult to determine on seven of the male skeletons. With the remaining four skeletons, the individual age was between 45 and 60 years of age.

Paleopathological changes on bones, as well as on jaws and teeth, were observed on seven skeletons. Table 2 shows that these are the skeletons no. 3, 10, 12, 15, 17, 21 and 28, one of which is an infant grave (no. 21).

Table 1: Zavojsko Lake (St. Nikola's Monastery) Mala Lukanja - elements of paleodemographic profiles

\begin{tabular}{|c|c|c|c|}
\hline $\begin{array}{c}\text { Archaeological } \\
\text { numeration }\end{array}$ & $\begin{array}{c}\text { Anthropological } \\
\text { numeration }\end{array}$ & Sex & Age \\
\hline $1 / 2$ & 1 & male & up to 50 years \\
\hline $2 / 2$ & 2 & infant & up to 1 year \\
\hline $3 / 2$ & 3 & male & over 45 years \\
\hline $4 / 2$ & 4 & infant & between 5 and 6 yeras \\
\hline $5 / 2$ & 5 & female & adult \\
\hline $6 / 3$ & 6 & infant & about 4 years \\
\hline $7 / 3$ & 7 & infant & about 2 years \\
\hline $8 / 3$ & 8 & infant & up to 1 year \\
\hline $9 / 3$ & 9 & male & adult \\
\hline $10 / 3$ & 10 & male & up to 60 years \\
\hline $11 / 3$ & 11 & male & adult \\
\hline $12 / 3$ & 12 & male & up to 45 years \\
\hline $13 /$ & 13 & male & adult \\
\hline $14 / 4$ & 14 & undetermined & adult \\
\hline $15 / 4$ & 15 & male $(?)$ & adult \\
\hline $16 / 4$ & 16 & infant & between 8 and 10 \\
& & & years \\
\hline
\end{tabular}




\begin{tabular}{|c|c|c|c|}
\hline $17 / 4$ & 17 & male & adult \\
\hline $18 / 5$ & 18 & infant & between 2 and 3 years \\
\hline $19 / 5$ & 19 & infant & up to 5 years \\
\hline $20 / 5$ & 20 & infant & between 6 and 8 years \\
\hline $21 / 5$ & 21 & infant & between 6 and 8 years \\
\hline $22 / 5$ & 22 & infant & about 2 years \\
\hline $23 / 5$ & 23 & undetermined & adult \\
\hline $24 / 5$ & 24 & undetermined & $\begin{array}{c}\text { probably up to } 20 \\
\text { years }\end{array}$ \\
\hline $25 / 5$ & 25 & undetermined & adult \\
\hline $26 / 5$ & 26 & male & adult \\
\hline $27 / 5$ & 27 & female $(?)$ & adult \\
\hline $28 / 5$ & 28 & male & adult \\
\hline
\end{tabular}

Table 2: The Zavojsko Lake (St. Nikola's Monastery) Mala Lukanja - an overview of paleopathological observations

\begin{tabular}{|c|c|c|c|}
\hline $\begin{array}{l}\text { Skeleton } \\
\text { number }\end{array}$ & Sex & Age & Paleopathological find \\
\hline 3 & male & over 45 & $\begin{array}{l}\text { Caries teeth, teeth cists and intra } \\
\text { vitam loss of teeth in both jaws. }\end{array}$ \\
\hline 10 & male & up to 60 years & $\begin{array}{c}\text { On both sides of the mandibula in- } \\
\text { tra vitam loss of all of the premolars } \\
\text { and molars. }\end{array}$ \\
\hline 12 & male & up to 45 years & $\begin{array}{l}\text { Exophytes on toracal and lumbal } \\
\text { vertebrae. Caries and intra vitam } \\
\text { loss of teeth in the mandibula. }\end{array}$ \\
\hline 15 & male (?) & adult & Osteophytes on lumbal vertebrae. \\
\hline 17 & male & adult & $\begin{array}{l}\text { Extreme depositing of osteophytes } \\
\text { on toracal and lumbal vertebrae. }\end{array}$ \\
\hline 21 & infant & $\begin{array}{l}\text { between } 6 \text { and } 8 \text { years. } \\
\text { Caries deciduous teeth } \\
\text { in the maxilla. Gribra } \\
\text { orbitalia in both of the } \\
\text { eye holes. }\end{array}$ & \\
\hline 28 & male & adult (senilis) & $\begin{array}{l}\text { Exophytes on toracal and lumbal } \\
\text { vertebrae. Intra vitam loss of all of } \\
\text { the teeth in maxilla. Healed fracture } \\
\text { of one of the upper ribbs (which, } \\
\text { due to incomplete preservation, can- } \\
\text { not be determined). }\end{array}$ \\
\hline
\end{tabular}


Table 3: THE ZAVOJSKO LAKE (ST. NIKOLA'S MONASTERY)

Mala Lukanja - cranial measures at disposal

\begin{tabular}{|c|c|c|c|c|c|c|c|}
\hline $\begin{array}{c}\text { Skeleton } \\
\text { number: }\end{array}$ & Sex: & $1^{*}$. & 8. & 9. & 13. & 17. & 66. \\
\hline & & & & & & & \\
\hline 1 & male & 186 & 145 & 101 & 100 & 110 & 107 \\
\hline 3 & male & $186+^{* *}$ & 148 & 98 & - & 117 & 100 \\
\hline 2 & male & $188+$ & 148 & 105 & - & 114 & 117 \\
\hline
\end{tabular}

* Osteometric marks according to R. Martin.

$* *+$ mark for the anthropological measure gained through reconstruction.

If jaws and teeth are observed separately, different types and locations of caries can be noticed, one tooth cist (peridontitis periapicalis chronica grahulomatosa), along with numerous teeth losses during one's lifetime (intra vitam). Caries teeth in both of the jaws were noticed only on skeleton no. 3, and in mandibula of the skeleton no. 12. Numerous cists were oticed on skeleton no. 3 (due to evolved caries). Loss of teeth in both of the jaws was again noticed at the skeleton no. 3 and only on madibulas of skeletons no. 10 and 12. The loss of maxilla teeth were noticed on skeleton no. 28. The infant skeleton no. 21 had caries teeth in the maxilla.

Destructive changes on spine were the most frequent paleopathlogical diagnoses on the examined skeletons from this necropolis. The changes include forming of osteophytes and exophytes on certain vertebrae. Ostheophytes, as a less destructive change, were noticed on lumbal vertebrae of the skeleton no. $15^{*}$, while on the skeleton no. 17 it is extreme depositing on toracal and lumbal parts of spine. Exophytes, as a developed form of bone destruction, were noticed on the skeletons no. 12 and 28, always on toracal and lumbal vertebrae.

Cribra orbitalia in a developed form was noticed in both of the eye holes of the infant skeleton 21.

Traumatic destruction is only noticeable on the skeleton of an old man no. 28. Its reliable position is difficult to determine, but it is obvious that one is dealing with a badly healed fracture (status post fracturam) of one of the upper ribbs, which was most probably caused by a fall from greater height.

Even though it is out of the titled frame of this paper, anthropometric features should also be mentioned. Due to the poor state of preservation, they could only be gained for three skulls, no. 1, 3 and 12 (see table 3).

Their length-width indexes vary between 73 and 80 point out that there are morphostructures at the bordering line between high mesocrane and brachicrane, and accompanied with planoccipitalia, they could be connected to the mid-Balkans mediaeval population (Mikić 1988).

Due to the poor state of preservation, examining anatomic variations, i.e. an attempt to establish family connections did not offer any indicative results. Os apicis sin was only noticed on the male skull no. 12. Here, the poor state of preservation was also the main cause.

As already mentioned, the cemetery around the church of Holy Resurrection (Svetog Vaznesenja) had its spacial dynamics which is chronologically conditioned. Still, it was archaeologically not completely investigated. This reduces its anthropological and paleodemographic reconstruction and interpretation.

As table 4 and its appendix show, for our analyses, all of the 140 archaeologically excavated skeletons were at our disposal, although very 
poorly and incompletely preserved. The 137 skeletons belong to the oldest part of the cemetery, from 15 th century, while the three male skeletons, which should be the oldest ones, come from the inside of the church (separately show non the appendix of table 4).

Due to poor state of preservation, out of 137 skeletons from the oldest part of the cemetery of the church of Svetog Vaznesenja, 22 skeletons could have not been determined according to thier sex. All of the male skeletons, 54 of them, were successfully determined. With female skeletons, 12 were successfully determined and three skeletons were determined with great probability. The number of infant skeletons is 46 .

Table 4: Zavojsko Lake (Church Svetog Vaznesenja) - elements of paleodemographic profiles

\begin{tabular}{|c|c|c|c|}
\hline $\begin{array}{c}\text { Archaeological } \\
\text { numeration }\end{array}$ & $\begin{array}{c}\text { Anthropological } \\
\text { numeration }\end{array}$ & Sex & Age \\
\hline \multicolumn{4}{|l|}{ sondage 1} \\
\hline skeleton no. 1 & 1 & robust male adult & \\
\hline skeleton no. 2 & 2 & $\begin{array}{c}\text { infant aged between } \\
8 \text { to } 10 \text { years }\end{array}$ & \\
\hline \multicolumn{4}{|l|}{ sondage 2} \\
\hline skeleton no. 3 & 3 & $\begin{array}{c}\text { infant aged between } \\
3 \text { to } 5 \text { years }\end{array}$ & \\
\hline skeleton no. 4 & 4 & $\begin{array}{c}\text { robust male over } 40 \\
\text { years }\end{array}$ & \\
\hline skeleton no. $4 / \mathrm{a}$ & 5 & $\begin{array}{c}\text { infant in the first } \\
\text { life year }\end{array}$ & \\
\hline skeleton no. 5/a & 6 & $\begin{array}{c}\text { female(?) up to } 60 \\
\text { years }\end{array}$ & \\
\hline skeleton no. $5 / \mathrm{b}$ & 7 & undetermined adult & \\
\hline skeleton no. $5 / \mathrm{c}$ & 8 & $\begin{array}{c}\text { infant in the first } \\
\text { life year }\end{array}$ & \\
\hline skeleton no. 6 & 9 & undetermined adult & \\
\hline skeleton no. 7 & 10 & undetermined adult & \\
\hline skeleton no. 8 & 11 & robust male adult & \\
\hline skeleton no. 9 & 12 & $\begin{array}{c}\text { infant aged between } \\
2 \text { to } 3 \text { years }\end{array}$ & \\
\hline skeleton no. 10 & 13 & male adult & \\
\hline skeleton no. 11 & 14 & male up to 50 years & \\
\hline skeleton no. 12 & 15 & $\begin{array}{c}\text { infant aged between } \\
10 \text { to } 12 \text { years }\end{array}$ & \\
\hline skeleton no. 13 & 16 & undetermined adult & \\
\hline skeleton no. 14 & 17 & male 30 to 35 years & \\
\hline
\end{tabular}




\begin{tabular}{|c|c|c|c|}
\hline skeleton no. 15 & 18 & male adult & \\
\hline skeleton no. 16 & 19 & $\begin{array}{c}\text { infant aged up to } 6 \\
\text { years }\end{array}$ & \\
\hline skeleton no. 17 & 20 & $\begin{array}{c}\text { robust male to } 45 \\
\text { years }\end{array}$ & \\
\hline skeleton no. 18 & 21 & male to 40 years & \\
\hline skeleton no. 19 & 22 & undetermined adult & \\
\hline skeleton no. 20 & 23 & male to 50 years & \\
\hline skeleton no. 21 & 24 & male adult & \\
\hline skeleton no. 22 & 25 & $\begin{array}{c}\text { robust male to } 40 \\
\text { years }\end{array}$ & \\
\hline skeleton no. 23 & 26 & undetermined adult & \\
\hline skeleton no. 24 & 27 & $\begin{array}{c}\text { infant aged between } \\
10 \text { to } 12 \text { years }\end{array}$ & \\
\hline skeleton no. 25 & 28 & male adult & \\
\hline skeleton no. 26 & 29 & $\begin{array}{c}\text { infant in the first } \\
\text { life year }\end{array}$ & \\
\hline skeleton no. 27 & 30 & $\begin{array}{l}\text { infant in the first } \\
\text { life months }\end{array}$ & \\
\hline skeleton no. 28 & 31 & male to 50 years & \\
\hline skeleton no. 29 & 32 & female adult & \\
\hline skeleton no. $29 / \mathrm{a}$ & 33 & $\begin{array}{c}\text { infant aged up to } 3 \\
\text { years }\end{array}$ & \\
\hline skeleton no. 30 & 34 & $\begin{array}{c}\text { infant aged between } \\
6 \text { to } 8 \text { years }\end{array}$ & \\
\hline skeleton no. 31 & 35 & undetermined & adult \\
\hline skeleton no. 32 & 36 & robust male & over 40 years \\
\hline skeleton no. 33 & 37 & robust male & to 60 years \\
\hline skeleton no. 34 & 38 & robust male & to 50 years \\
\hline skeleton no. 35 & 39 & robust male & over 40 years \\
\hline skeleton no. 36 & 40 & & infant in the first life year \\
\hline skeleton no. 37 & 41 & $\begin{array}{c}\text { infant aged up to } 2 \\
\text { years }\end{array}$ & \\
\hline skeleton no. 38 & 42 & male & to 50 years \\
\hline skeleton no. 39 & 43 & $\begin{array}{c}\text { infant aged up to } 2 \\
\text { years }\end{array}$ & \\
\hline skeleton no. 40 & 44 & male & to 50 years \\
\hline skeleton no. 41 & 45 & male & to $21 / 23$ years \\
\hline skeleton no. 42 & 46 & male & to 30 years \\
\hline skeleton no. 43 & 47 & $\begin{array}{c}\text { infant aged between } \\
12 \text { to } 15 \text { years }\end{array}$ & \\
\hline
\end{tabular}




\begin{tabular}{|c|c|c|c|}
\hline skeleton no. 44 & 48 & male & to $21 / 23$ years \\
\hline skeleton no. 45 & 49 & undetermined & adult \\
\hline skeleton no. 46 & 50 & undetermined & adult \\
\hline skeleton no. 47 & 51 & male & to 45 years \\
\hline skeleton no. 48 & 52 & undetermined & undetermined \\
\hline skeleton no. 49 & 53 & robust male & to 40 years \\
\hline skeleton no. 50 & 54 & male & to 50 years \\
\hline skeleton no. 51 & 55 & robust male & undetermined \\
\hline skeleton no. 52 & 56 & undetermined & undetermined \\
\hline skeleton no. 53 & 57 & male & to 60 years \\
\hline skeleton no. 54/a & 58 & robust male & to 50 years \\
\hline skeleton no. $54 / \mathrm{b}$ & 59 & & $\begin{array}{c}\text { infant aged between } 6 \text { to } 8 \\
\text { years }\end{array}$ \\
\hline \multicolumn{4}{|l|}{ sondage 3} \\
\hline 1 & 60 & undetermined & undetermined \\
\hline 2 & 61 & $\begin{array}{l}\text { infant in the first } \\
\text { life months }\end{array}$ & \\
\hline 3 & 62 & $\begin{array}{c}\text { infant in the first } \\
\text { life year }\end{array}$ & \\
\hline 4 & 63 & $\begin{array}{c}\text { infant aged between } \\
8 \text { to } 10 \text { years }\end{array}$ & \\
\hline 5 & 64 & $\begin{array}{c}\text { infant aged up to } 3 \\
\text { years }\end{array}$ & \\
\hline 6 & 65 & $\begin{array}{c}\text { infant aged up to } 3 \\
\text { years }\end{array}$ & \\
\hline 7 & 66 & $\begin{array}{c}\text { infant in the first } \\
\text { life year }\end{array}$ & \\
\hline 8 & 67 & $\begin{array}{l}\text { infant in the first } \\
\text { life months }\end{array}$ & \\
\hline 9 & 68 & $\begin{array}{c}\text { infant aged up to } 2 \\
\text { years }\end{array}$ & \\
\hline 10 & 69 & female(?) & to $21 / 23$ years \\
\hline 11 & 70 & $\begin{array}{c}\text { infant aged up to } 6 \\
\text { years }\end{array}$ & \\
\hline 12 & 71 & $\begin{array}{c}\text { infant aged between } \\
8 \text { to } 10 \text { years }\end{array}$ & \\
\hline 13 & 72 & undetermined & undetermined \\
\hline 14 & 73 & robustna female & to 30 years \\
\hline 15 & 74 & robust male & to 30 years \\
\hline 16 & 75 & undetermined & adult \\
\hline
\end{tabular}




\begin{tabular}{|c|c|c|c|}
\hline 17 & 76 & $\begin{array}{c}\text { infant aged between } \\
8 \text { to } 10 \text { years }\end{array}$ & \\
\hline 18 & 77 & $\begin{array}{c}\text { infant aged between } \\
6 \text { to } 8 \text { years }\end{array}$ & \\
\hline 19 & 78 & undetermined & undetermined \\
\hline 20 & 79 & female & to 40 years \\
\hline 21 & 80 & $\begin{array}{l}\text { infant aged between } \\
12 \text { to } 15 \text { years }\end{array}$ & \\
\hline 22 & 81 & $\begin{array}{l}\text { infant aged between } \\
8 \text { to } 10 \text { years }\end{array}$ & \\
\hline 23 & 82 & robust male & to 60 years \\
\hline 24 & 83 & male & to 35 years \\
\hline 25 & 84 & male & adult \\
\hline 26 & 85 & male & to 60 years \\
\hline 27 & 86 & female & to 60 years \\
\hline 28 & 87 & male & to 40 years \\
\hline 29 & 88 & robust male & adult \\
\hline 30 & 89 & robust male & to 40 years \\
\hline 31 & 90 & $\begin{array}{l}\text { infant aged between } \\
6 \text { months to } 3 \text { years }\end{array}$ & \\
\hline 32 & 91 & $\begin{array}{c}\text { infant aged up to } 3 \\
\text { years }\end{array}$ & \\
\hline 33 & 92 & undetermined & undetermined \\
\hline 34 & 93 & undetermined & undetermined \\
\hline 35 & 94 & undetermined & undetermined \\
\hline 36 & 95 & male & to 40 years \\
\hline 37 & 96 & undetermined & undetermined \\
\hline 38 & 97 & undetermined & undetermined \\
\hline 39 & 98 & male & to 50 years \\
\hline 40 & 99 & male & to 40 years \\
\hline \multicolumn{4}{|c|}{ sondage 4} \\
\hline 1 & 100 & $\begin{array}{c}\text { infant aged up to } 2 \\
\text { years }\end{array}$ & \\
\hline 2 & 101 & gracile female & to 40 years \\
\hline 3 & 102 & female & to 50 years \\
\hline $4 / \mathrm{a}$ & 103 & male & over 40 years \\
\hline $4 / b$ & 104 & male & to 60 years \\
\hline 5 & 105 & $\begin{array}{c}\text { infant aged up to } 6 \\
\text { years }\end{array}$ & \\
\hline 6 & 106 & male & over 50 years \\
\hline
\end{tabular}




\begin{tabular}{|c|c|c|c|}
\hline 7 & 107 & gracile female & to 40 years \\
\hline 8 & 108 & $\begin{array}{l}\text { infant aged between } \\
6 \text { months to } 3 \text { years }\end{array}$ & \\
\hline 9 & 109 & robust male & to 40 years \\
\hline 10 & 110 & $\begin{array}{c}\text { infant aged up to } 15 \\
\text { years }\end{array}$ & \\
\hline 11 & 111 & female & to 60 years \\
\hline 12 & 112 & undetermined & undetermined \\
\hline 13 & 113 & robust male & adult \\
\hline 14 & 114 & male & to 50 years \\
\hline 15 & 115 & male & to 60 years \\
\hline 16 & 116 & $\begin{array}{c}\text { infant aged up to } 2 \\
\text { years }\end{array}$ & \\
\hline \multicolumn{4}{|c|}{ sondage 5} \\
\hline 1 & 117 & $\begin{array}{c}\text { infant aged between } \\
3 \text { to } 4 \text { years }\end{array}$ & \\
\hline 2 & 118 & $\begin{array}{c}\text { infant aged up to } 15 \\
\text { years }\end{array}$ & \\
\hline 3 & 119 & robust female & to 40 years \\
\hline 4 & 120 & $\begin{array}{c}\text { infant aged up to } 3 \\
\text { years }\end{array}$ & \\
\hline 5 & 121 & $\begin{array}{c}\text { infant in the first } \\
\text { life year }\end{array}$ & \\
\hline 6 & 122 & undetermined & undetermined \\
\hline 7 & 123 & male & to 45 years \\
\hline 8 & 124 & male & to 50 years \\
\hline $9 / \mathrm{a}$ & 125 & female (probably) & adult \\
\hline $9 / b$ & 126 & $\begin{array}{c}\text { infant aged up to } 2 \\
\text { years }\end{array}$ & \\
\hline 10 & 127 & female & to 50 years \\
\hline 11 & 128 & female & to 40 years \\
\hline 12 & 129 & $\begin{array}{c}\text { infant aged between } \\
6 \text { to } 8 \text { years }\end{array}$ & \\
\hline $1 ?$ & 130 & $\begin{array}{c}\text { infant aged between } \\
5 \text { to } 6 \text { years }\end{array}$ & \\
\hline 14 & 131 & male & to 45 years \\
\hline 15 & 132 & $\begin{array}{c}\text { infant aged up to } 5 \\
\text { years }\end{array}$ & \\
\hline \multicolumn{4}{|c|}{ sondage 6} \\
\hline 1 & 133 & male & adult \\
\hline 2 & 134 & male & over 20 years \\
\hline
\end{tabular}




\begin{tabular}{|c|c|c|c|}
\hline 3 & 135 & male & to 60 years \\
\hline 4 & 136 & male & to 40 years \\
\hline 5 & 137 & female & to 60 years \\
\hline
\end{tabular}

Appendix to table 4: Anthropological content of the inside of the Svetog Vaznesenja church

Grave no. 1: Poorly preserved skeleton of a robust male aged up to 40 years.

2: Incompletely preserved skeleton of a robust male aged up to 60 years. Skull calotte was preserved:

M. 1 (maximum skull length) $175 \mathrm{~mm}$

M. 8 (maximum skull width) 146

M. 9 (smallest forehead width) 101

Paleopathological find: Extreme exophytes on lumbal vertebrae, the two lowest are blocked together.

3: Poorly preserved male skeleton aged up to 35 years.

Age structure of this specific skeleton group could have been calculated according to the data for 102 individual skeletons. As table 4 shows, individual biological age could have been determined for 4-3 male, 13 female and 46 infant skeletons. Due to the very poor state of preservation, this kind of data was not obtained for the remaining 35 skeletons.

It turned out that the relatively small group of females (13) had an average life length of almost 43 years $(42,8)$. An average man burried at this part of the cemetery did not live longer than 40 $(39,6)$. The large group of infants (46) mostly died in the first life years, while their average life length did not exceed 5 years $(5,2)$. All of these results, especially the great discordance between sex, shall be discussed in the next part of this paper.

Paleopathological profile (see table 5) of the inhabitants burried at the older part of the cemetery, next to the church of Svetog Vaznesenja, shows that out of 137 individuals, 39 show traces of paleopathological destructions which lasted long enough to leave traces on bones or teeth. Out of that number, 23 are male skeletons (54 in all), 8 are female (15 in all), while 7 belong to infants (46 in all). The sex of only one skeleton remained undetermined (22 in all). The number of diagnoses (64) is greater that the number of skeletons on which they were observed (39), while 43 pathological diagnoses concearn jaws and teeth.

The same as with the skeleton group excavated at the older location, near the St. Nikola's monastery, our examining beginns with observing jaws and teeth.

Caries is noticeable already at children's age. On deciduous molars it was observed in four cases (no. 15, 63, 65 and 76). Apart from caries, cribra orbitalia was also observed on children's skulls. These include three cases, on skulls no. 65,108 and 116. On the seventh child's skull with paleopathological changes (no. 47), the diagnosis concearns the hole in the right pelvis part, which is considered the direct Causa mortis, even though the individual was less than 15 years of age.

With adults, whose growth and development are considered to be finished according to different criteria, jaws and teeth were endangered as well. Caries is very various in type and almost all of the variations were present. It can be divided into jaws after its positioning. In five cases, it was discovered in both of the jaws (no. 37, 42, 44, 74 and 101), again in five cases only in the mandibula (no. 73, 82, 86, 107 and H9) and in two cases only in the maxilla (no. 36 and 39).

Teeth cists were also divided according to their position within jaws, all after table 5. Cists in both of the jaws were found on three skulls (no. 42, 44 and 101), in two cases only in the maxilla (no. 37 and 39) and again in two cases only in the mandibula (no. 82 and 107).

Partial tooth loss during one's lifetime oc- 
Table 5: Zavojsko Lake (The Church Of Svetog Vaznesenja) - an

overview of paleopathological observations

\begin{tabular}{|c|c|c|c|}
\hline $\begin{array}{l}\text { Antropologi- } \\
\text { cal number }\end{array}$ & Sex & Age & Paleopathological opservation \\
\hline 6 & $\mathrm{~F}(?)$ & to 60 years & $\begin{array}{c}\text { Loss of a larger number of premolar and molar } \\
\text { teeth in mandibula intra vitam. }\end{array}$ \\
\hline 13 & M & adult & $\begin{array}{l}\text { Erosion of the osteomielitis leutica type on } \\
\text { skull bones. Loss of more than a half of man- } \\
\text { dibula teeth intra vitam. }\end{array}$ \\
\hline 14 & M & to 50 years & $\begin{array}{l}\text { Extreme exophytes on lumbal vertebrae. Badly } \\
\text { healed doublé fracture of the left femur (in } \\
\text { the middle of diaphysis and knee ankle). Well } \\
\text { healed fracture of the plate part of the right } \\
\text { scapula. Intra vitam loss of all of the back } \\
\text { teeth (molars) in both of the jaws. }\end{array}$ \\
\hline 15 & $\mathrm{~N}$ & $10 / 12$ years & Caries on all of the deciduous teeth. \\
\hline 20 & M & to 45 years & $\begin{array}{l}\text { Status post fracturam of one rib (which is dif- } \\
\text { ficult to determine beacuse of poor preserva- } \\
\text { tion state). Intra vitam loss of teeth in both of } \\
\text { the jaws. }\end{array}$ \\
\hline 23 & M & to 50 years & $\begin{array}{l}\text { On neck vertebrae huge destruction which } \\
\text { led to corporal assimetry. Visible exostoses on } \\
\text { tibias. }\end{array}$ \\
\hline 25 & M & to 40 years & $\begin{array}{l}\text { Exophytes on lumbal vertebrae. Intra vitam } \\
\text { loss of teeth in the mandibula. }\end{array}$ \\
\hline 26 & $?$ & adult & $\begin{array}{l}\text { Sacrum and Os coxae dexter completely } \\
\text { obliterated. }\end{array}$ \\
\hline 28 & M & adult & Periostitis of the left tibia and left fibula. \\
\hline 31 & $\mathrm{M}$ & to 50 years & $\begin{array}{l}\text { Visible assimetrical destruction of lumbal ver- } \\
\text { tebrae. Intra vitam loss of all fo the mandibula } \\
\text { premolars and molars. }\end{array}$ \\
\hline 36 & M & over 40 years & $\begin{array}{l}\text { Well healed fracture of a rib (which could not } \\
\text { be located due to poor state of preservation). } \\
\text { Intra vitam loss of both of the mandibular pre- } \\
\text { molar son the left. Caries on maxillar teeth. }\end{array}$ \\
\hline 37 & M & to 60 & $\begin{array}{l}\text { Teeth cists on the left maxilla side, as well as } \\
\text { caries teeth. }\end{array}$ \\
\hline 38 & M & to 50 & Intra vitam loss of mandibula molars. \\
\hline 39 & M & over & $\begin{array}{l}\text { Caries and teeth cists in maxilla. Intra vitam } \\
\text { loss of teeth in the mandibula. }\end{array}$ \\
\hline 42 & M & to 50 & $\begin{array}{l}\text { Intra vitam loss of a large number of teeth in } \\
\text { both of the jaws and teeth cists. }\end{array}$ \\
\hline 44 & $\mathrm{M}$ to 50 years & & $\begin{array}{l}\text { Caries teeth in both of the jaws, teeth cists and } \\
\text { intra vitam loss of six teeth. }\end{array}$ \\
\hline
\end{tabular}




\begin{tabular}{|c|c|c|c|}
\hline 47 & $\mathrm{~N}$ & $12 / 15$ years & $\begin{array}{l}\text { Right pelvis half perforated circularly in the } \\
\text { middle. Opening on the outer side } 1 \mathrm{~cm} \text {, and } \\
\text { on the inner side about } 1,5 \mathrm{~cm} \text {. This injury } \\
\text { indicates the causa mortis. }\end{array}$ \\
\hline 51 & M & to 45 years & Extreme exophytes on lumbal vertebrae. \\
\hline 54 & M & to 50 years & $\begin{array}{c}\text { Badly healed fracture of colum femoris dexter. } \\
\text { Visible loss of ad longitudinem. }\end{array}$ \\
\hline 63 & $\mathrm{~N}$ & $8 / 10$ years & Caries on mandibular deciduous teeth. \\
\hline 65 & $\mathrm{~N}$ & about 3 years & $\begin{array}{l}\text { Cribra orbitalia. Caries on deciduous molars } \\
\text { in both of the jaws. }\end{array}$ \\
\hline 69 & $\mathrm{~F}(?)$ & to $21 / 23$ years & Intra vitam loss of mandibula's first left molar. \\
\hline 73 & $\mathrm{~F}$ & to 30 years & Molar caries in mandibula. \\
\hline 74 & M & to 30 years & $\begin{array}{l}\text { Caries present in both of the jaws. Intra vitam } \\
\text { loss of premolares on the left side. }\end{array}$ \\
\hline 76 & $\mathrm{~N}$ & $8 / 10$ years & Caries on deciduous molars. \\
\hline 82 & M & to 60 years & $\begin{array}{l}\text { Intra vitam loss of all of the teeth in the max- } \\
\text { illa, due to which the palatal bow is complete- } \\
\text { ly flat. Intra vitam loss of all of the premolars } \\
\text { and molars in the mandibula. Dental illness } \\
\text { and teeth cists in the frontal zone. }\end{array}$ \\
\hline 86 & $\mathrm{~F}$ & to 60 years & $\begin{array}{l}\text { Loss of all of the mandibula teeth intra vitam, } \\
\text { except one caries molar. }\end{array}$ \\
\hline 87 & M & to 40 years & $\begin{array}{l}\text { Arthritis on the whole spine. Visible discus } \\
\text { destruction. }\end{array}$ \\
\hline 89 & M & to 40 years & $\begin{array}{c}\text { Destruction of the osteomielitis leutica type on } \\
\text { skull fragments. }\end{array}$ \\
\hline 99 & M & to 40 years & Loss of only one tooth in both of the jaws. \\
\hline 101 & $\mathrm{~F}$ & to 40 years & $\begin{array}{l}\text { Caries teeth in both of the jaws, teeth cists and } \\
\text { intra vitam loss of teeth. }\end{array}$ \\
\hline 104 & M & to 60 years & No teeth in the maxilla. \\
\hline 106 & M & over 50 years & $\begin{array}{l}\text { Osteophytes on lumbal vertebrae. Only two } \\
\text { molars left in the right maxilla part. }\end{array}$ \\
\hline 107 & $\mathrm{~F}$ & to 40 years & $\begin{array}{l}\text { Caries teeth in the mandibula, teeth cists and } \\
\text { intra vitam loss of numerous teeth. }\end{array}$ \\
\hline 108 & $\mathrm{~N}$ & & $\begin{array}{c}6 / 8 \text { years } \\
\text { Cribra orbitalia. }\end{array}$ \\
\hline 116 & $\mathrm{~N}$ & about 2 years & Cribra orbitalia. \\
\hline 119 & $\mathrm{~F}(?)$ & to 40 years & $\begin{array}{l}\text { Caries and intra vitam teeth loss in the man- } \\
\text { dibula. Lumbal vertebrae grown together in a } \\
\text { block - Morbus Becterew. }\end{array}$ \\
\hline 123 & M & to 45 years & $\begin{array}{l}\text { Extreme exophytes on lumbal vertebrae with } \\
\text { corpus destruction. }\end{array}$ \\
\hline 137 & $\mathrm{~F}$ & to 60 years & $\begin{array}{l}\text { Almost all of the teeth alveoles in both of the } \\
\text { jaws atrophied. }\end{array}$ \\
\hline
\end{tabular}




\begin{tabular}{|c|c|c|c|c|c|c|c|c|c|c|c|c|c|c|c|c|c|c|}
\hline 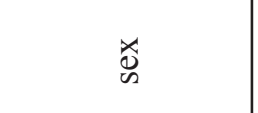 & $\Sigma$ & $\Sigma$ & $\Sigma$ & $\Sigma$ & $\Sigma$ & $\Sigma$ & $\underset{\Sigma}{\Sigma}$ & $\Sigma$ & $\underset{\Sigma}{\Sigma}$ & $\Sigma$ & & & $\Sigma$ & & $\Sigma$ & $\underset{\Sigma}{\tilde{\Sigma}}$ & $\Sigma$ & $\underset{\underbrace{}}{\overparen{\underbrace{}}}$ \\
\hline$\dot{\vec{I}}$ & 1 & 1 & ' & ' & $\underset{m}{m}$ & ' & 1 & 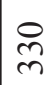 & ' & 1 & $\Sigma$ & $\Sigma$ & $\hat{N}$ & $\Phi$ & $\stackrel{\sim}{\approx}$ & ' & 1 & 1 \\
\hline$\dot{\vec{I}}$ & 1 & 1 & 1 & ' & in & 1 & ' & ' & $\stackrel{\wp}{f}$ & ' & 1 & 1 & ' & $\begin{array}{l}\infty \\
\infty \\
\infty\end{array}$ & ' & ' & $\stackrel{\infty}{\stackrel{q}{q}}$ & . \\
\hline 8 & 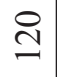 & 1 & 1 & ' & 1 & 1 & 1 & ' & 1 & 1 & 1 & $\begin{array}{l}\infty \\
\stackrel{n}{\sigma}\end{array}$ & ' & $\stackrel{\infty}{\stackrel{+}{+}}$ & ' & ' & ' & ' \\
\hline in & 1 & 1 & $\stackrel{\infty}{\sim}$ & নे & 1 & 1 & 1 & ' & 1 & 1 & ' & ' & ' & ' & 1 & ' & 1 & 1 \\
\hline in & ' & 1 & f & $\bar{n}$ & 1 & 1 & 1 & ' & 1 & 1 & ' & ' & ' & 1 & I & ' & 1 & 1 \\
\hline in & ' & 1 & 요 & กै & 1 & 1 & 1 & ' & 1 & 1 & 1 & ' & ' & 1 & ' & ' & 1 & 1 \\
\hline$\dot{n}$ & 1 & 1 & $\hat{n}$ & $\stackrel{\infty}{m}$ & 1 & 1 & 1 & ' & 1 & 1 & ' & ' & ' & ' & ' & ' & 1 & 1 \\
\hline$\stackrel{\infty}{+}$ & ' & 1 & $\infty$ & $\nabla$ & 1 & 1 & ' & ' & 1 & 1 & ' & ' & ' & ' & ' & ' & 1 & 1 \\
\hline$\ddot{q}$ & ' & 1 & $\tilde{n}$ & $\stackrel{\vartheta}{\approx}$ & ' & ' & ' & ' & 1 & 1 & ' & 1 & 1 & 1 & ' & ' & ' & 1 \\
\hline$\dot{\sim}$ & $\hat{n}$ & ' & 寻 & ले & ' & ' & 1 & ' & 1 & 1 & ' & ' & ' & ' & ' & ' & 1 & ' \\
\hline 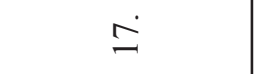 & $\stackrel{\text { తి }}{ }$ & ' & $\cong$ & $\equiv$ & 1 & ' & 1 & ' & 1 & 1 & 1 & ' & ' & ' & 1 & ' & 1 & 1 \\
\hline$\sigma^{\circ}$ & 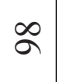 & $\overrightarrow{0}$ & $\tilde{\sigma}$ & $\hat{a}$ & 1 & $\bar{a}$ & 1 & $\stackrel{\infty}{\sigma}$ & 1 & $\sigma$ & ๙ & ' & : & ' & ' & $\alpha$ & $\stackrel{\infty}{\sigma}$ & $\stackrel{\infty}{\sigma}$ \\
\hline$\infty$ & 守 & $\stackrel{0}{ \pm}$ & 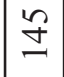 & 过 & 1 & $\vec{n}$ & $\hat{n}$ & $\stackrel{\sim}{2}$ & 1 & $\exists$ & $\stackrel{\text { I }}{ \pm}$ & ' & $n$ & ๑ & 守 & $\ddot{n}$ & $\exists$ & $\stackrel{\mathcal{I}}{ \pm}$ \\
\hline$\doteq$ & 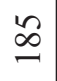 & $\stackrel{n}{=}$ & $\mathscr{\infty}$ & $\underset{\infty}{\infty}$ & 1 & 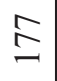 & $\Xi$ & $\infty$ & 1 & $\stackrel{\Delta}{I}$ & $\stackrel{0}{2}$ & ' & $\underset{\infty}{\infty}$ & $\stackrel{\infty}{\beth}$ & $\underset{-}{\infty}$ & 인 & $\stackrel{n}{=}$ & $\stackrel{2}{\Sigma}$ \\
\hline 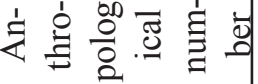 & in & $\Xi$ & li & $\infty$ & $\vec{n}$ & $\hat{n}$ & $i n$ & $\infty$ & $\stackrel{⿱}{2}$ & $\approx$ & হু & $\stackrel{m}{=}$ & $\cong$ & $\stackrel{9}{=}$ & 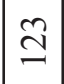 & $\bar{m}$ & $\begin{array}{l}0 \\
\cong\end{array}$ & $\hat{n}$ \\
\hline 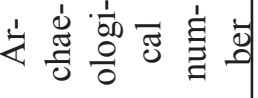 & $\stackrel{\Re}{\stackrel{\Im}{\gamma}}$ & $\stackrel{N}{=}$ & $\underset{\sim}{N}$ & $\frac{N}{f}$ & $\underset{⿱}{\stackrel{f}{f}}$ & $\stackrel{\mathfrak{a}}{a}$ & $\stackrel{\sim}{\stackrel{n}{n}}$ & $\frac{n}{f}$ & $\stackrel{m}{n}$ & $\frac{m}{\grave{m}}$ & $\stackrel{m}{o}$ & $\frac{m}{8}$ & $\underset{ \pm}{ \pm}$ & $\frac{n}{m}$ & $\stackrel{n}{r}$ & $\stackrel{n}{\ni}$ & $\stackrel{0}{\forall}$ & $\stackrel{0}{i n}$ \\
\hline
\end{tabular}


cured very often, especially in the mandibula. Eleven cases were discovered $(6,13,25,31,36$, $38,39,69,86,107$ and 119). In one case, loss of maxilla teeth was noticed (no. 106), while the loss of teeth in both of the jaws was examined on seven individuals (no. 14, 20, 44, 74, 82, 99 and 101). Loss of all of the teeth was encountered on one individual (no. 104), as well as in both of the jaws on skull no. 137, which is a unique case.

On spines of adult individuals burried at this part of the cemetery next to the Svetog Vaznesenja church, osteophytes were noticed on the skeleton no. 106. Exophytes were noticed on four skeletons no. 14, 25, 51 and 123. Destruction of lumbal vertebrae lead to spine deformation on skeleton no. 31, while the same change was noticed on cervical vertebrae of the skeleton no. 23. At skeleton no. 119 a block of ossified lumbal vertebrae was formed, while on the skeleton no. 87 the whole spine was ossified.

Exostases were noticed on skeleton no. 23 on its tibias.

On skeleton no. 26, on its right side, the Sacrum and Os coxae were completely grown together, which was a unique case.

Fractures were discovered on four skeletons, but in five cases. Only two out of the five cases were well healed (no. 14 - Scapula; no. 36 - Os costae). Badly healed fractures were discovered on skeletons no. 14 (left femur), no. 20 (Os costae) and no. 50 (Colum femoris dex.).

Periostitis was noticed only on the left tibia and on the left fibula of the skeleton no. 28. Still, the diagnosis for the skulls of skeletons no. 13 and 89 is osteomielitis leutica.

Out of three skeletons discovered in the inside of the church, only on one (no. 2) extreme exophytes on lumbal vertebrae were noticed and L4 and L5 were grown together.

Table 6 shows primary skull measurments, as well as the main measures of long bones, so some of the skull indexes were posible to calculate and the most probable corporal height of the individuals burried on this part of the cemetery. Primary measures were gained for 15 skulls and post-cranial measurments of long bones for only 8 skeletons.

For 15 skulls (see table 6), divided into sex, the calculated longitudinal and width indexes were mostly gained for males. These include 13 index values with the width variation from 78,38 to 85,31 . Five skulls belong to high mesocrane group, while the rest of eight skulls belong to brachicrane group. The two measured female skulls have brachicrane indexes - 80,68 and 80,89.

According to the quoted methodology, for calculating corporal height according to the regression relationships of long bones, the data was gained that height of the male individuals was between $168 \mathrm{~cm}$ and $176 \mathrm{~cm}$, which makes the average height of slightly more than $171 \mathrm{~cm}$. For females, only one skeleton was at disposal (no. 119), whose height is about $159 \mathrm{~cm}$.

Next to each archaeological number of grave/skeleton, there is also the number of sondage. Due to incomplete state of preservation, apart from femur and humerus, the rest of the long bones were not anthropologically measured.

In order to gain the best image of anthropological features of the here mentioned mediaeval inhabitants, we shall here try to summarize and interpret paloedemographical and paleopathological elements. These elements are presented according to the location and dating of the cemeteries. Following of anatomic variations offered very little data. That is one case of suttura metopica (no. 83), one case of fisura metopica (no.114) and one occurance of Os Incae uniratitum with dimensions $11 \times 5 \mathrm{~cm}$ (on skull no. 115). Still, apart from the very poor state of preservation, anthropological results fit into the anthropological profile of the mediaeval population of the Mid Balkans which is related to the authochtonous population (Mikić 1988). 


\section{DISCUSSION AND SUMMARY}

It was already stated that the study of this human osteological material was conducted in 1988 , in the same year when it was excavated. Since there was no archaeological publication, the anthropological survey was conducted in 2011. It was also stated that these cemeteries close to two sacral objects were only partly excavated. The state of preservation was so poor that only a very low number of anthropological measures was obtained. On infant skeletons, morphological observation was often reduced to minimum. Their age was determined, but not their sex. In most of the cases of adult skeletons, it was posible to determine both sex and age. Due to the lack of anthropological measures, certain discriminant functions were not performed, but the preserved elements (se tables 3 and 6) in both cases indicated that one was dealing with the authochtonous population in the late mediaeval of the Mid Balkans.

The monastery cemetery, which is older, dates back between $12^{\text {th }}$ and $14^{\text {th }}$ century. Since only 28 skeletons were excavated, we can say that only its smaller part is known (according to some estimations it is only one quarter of the whole necropolis). Because of that, any paleodemographic summarizing would be very variable. It can only be repeated that most of the infants died in their early life stages. The average life length of women was not obtained, while the oldest male individual reached his age of 60 years (table 1).

Paleopathological observation concern seven skeletons (table 2). Only one of them is an infant skeleton with caries teeth in the maxilla. Cribra orbitalia shows reaction on anemia which is developed in the early infanta ge (Stuart - Macadam 1985) and which was encountered on skeleton no. 21.

Teeth and alveola illnesses encountered on this group of skeletons (table 2) show that they occured often. Loss of teeth during one's lifetime is the ultimate result, supported with paradonthosis.
It is interesing to mention that up to the present day, the bacteria which directly cause this was not isolated. Some scientists, such as C.W. Drake and his colleagues (Drake et al. 1993), think that these include more than 40 bacteriae.

Paleopathological changes were observed on bones of six male adults. If we would wish to systematize them, they would include three different paleopathological categories (according to table 2). The first one includes jaws and teeth (4 finds on 6 skeletons), rheumatic changes (4 cases), and one fracture on the thoracal skeleton part of an old man no. 28 (Status post fracturam os costae).

About women burried on the cemetery next to the monastery of St. Nikola, neither in the archaeologically nor in the anthropologically examined part, there are no paleopathological data, independent of the number of excavated skeletons.

Just like in the case of skeletons discovered next to the monastery of St. Nikola, the methodology of determining sex and age of adults and infants was already interpreted. In comparison to the first group of skeletons, this one is much bigger, but also much younger. It is dated into the period from $15^{\text {th }}$ to $17^{\text {th }}$ century. Apart from this difference in dating, there is also a difference in geography. Even through they belong to the same micro-region, there is a distance of about $10 \mathrm{~km}$ between these two sacral objects.

The first paleodemographic result, gained from table 4, is a big discordance between males, females and children. This sample includes 54 men, 15 women and 46 children from the earliest life stage, but also 22 adult skeletons whose sex was not determined. Since neither during archaeological excavation nor during the analyses there were no skeletons in fetal stage, there is a possibility that children were brought to these medieval churches for certain reasons. It is well known that, apart from their religious role, medieval monasteries also played health and social roles, which should be pointed out and considered. It is quite 
possible that due to their role of such a kind, there is discordance between male and female individuals discovered. Because of this, it was not used for paleodemographic studies, for which there were twenty instructions given by J. Nemsekeri already in 1970 (Acsadi and Nemeskeri, 1970).

The age reached was gained for 43 male, 13 female and 46 infant skeletons. The total of 35 skeletons remained without these demographic elements. The data named for the average life length should be considered as relative, because this cemetery was only partly excavated. Men lived approximately 43 years long, women about 40 years and infants about 5 years. We are of the opinion that the discordance between sex does not allow structurating of a so-called "time table", so these results are only regarded as relative and certainly not definite.

Since the cemeteries are not connected to any settlement with an inner and an outer dynamics, we were here dealing with one cemetery part which was connected to the church and certainly was a choice of certain number of individuals, who were present here in a certain moment because of certain needs, most likely out of their usual settlements.

Just like in the case of human osteological material discovered next to the monastery of St. Nikola, on the osteological material found near the church of Svetog Vaznesenja, paleopathological changes were observed separately on jaws and teeth and on cranial and post-cranial skeleton (Table 5).

Caries was encountered on infants (4 cases), as well as on adults. Caries in both of the jaws was observed on five individuals, only in mandibula also on five individuals and only in maxilla only on two. In three cases, the accompaning cists were discovered in both of the jaws, and two times each in mandibula and maxilla. Intra vitam loss of teeth in mandibula was observed eleven times. Loss of teeth on maxilla were noticed only once and in both of the jaws in seven cases. There were also cases of complete loss of teeth, once in the maxilla and in both also on only one individual.

When spine and arthritic changes are concerned, it should be pointed out that they are the most frequent ones. They were noticed on nine skeletons, as well as on one skeleton excavated in the inside of the church of Svetog Vaznesenja.

Unspecific diseases, like periostitis, were noticed on one skeleton. Since the whole human osteological material was burried in a common grave after the archaeological and anthropological research, it was not posible to gathe samples for any future labratory analyses of two cases diagnosticized as osteomielitis leutica.

Metabolic diseases, like anemia, were noticed only on infant skeletons, i.e. in three cases.

As for traumas of adult individuals, they were all random (5 finds according to table 5). At the infant skeleton no. 4-7 the pelvis was pierced with a sharp object and this was understood as the direct causa mortis, whose circumstances were difficult to interpret.

Summarized, our conclusions would be:

According to the elements which stood at our disposal, we were not able to recognize any continuity between the anthropological contents of these two cemeteries, even though they belong to the same micro-region and chronologically continue one after the other.

Since both of the cemeteries are next to hurches, the great percentual discordance between sex, with numerous infants can only be explained with the fact that the people burried here were chosen according to certain criteria.

The same conclusion is reached because of the great number of infant skeletons in the early life stages, but also because of the lack of subadult individual sor those in fetal stadium.

There were no elements for a paleodemographic study of size of a hypothetic settlement, since we were dealing with cemeteries closet o churches with no usual biologic structure. 
The paleopathologic analysis showed that oral hygiene (of jaws and teeth) of these medieval people was very poor, that they often suffered of rheumatism and that there were no deliberately caused traumas (except on one infant skelton). All of this shows that there is a certain choice of individuals burried on these two cemeteries.

Finally, our goal was to examine and publish this huge anthropological material, even though the state of preservation of the osteological material was poor. We are obliged to do so because of our profesional duty on one hand and on the other, a very bad treatment of human osteological remains after archaeological excavations, which is very often encountered in this region.

\section{BIBLIOGRAPHY}

BАCH H. 1965.

Zur Berechnung der Korperhöhe aus den langen Gliedmassenknochen weiblicher Skelette. Anthrop. Anz.29:12-21.

BERRY G. A. and BERRY R. J. 1967.

Epigenetic variations in the human cranium. J. Anat. 101: 361-379.

BREITINGER E. 1938.

Zur Berechnung der Korperhöhe aus den langen Gliedmassenknochen. Anthrop. Anz. 14; 249274.

\section{BROTHWELL D.R. 1965.}

Digging up Bones. London.

\section{DRAKE C.W. et al. 1993.}

The distribution and interrelationship of Actinobacillus actinomvcetemeomitans Prophvromons gingivitis, Prevatella intermedia and BANA scores among older adults. J. Periodentologv 64: 89-94.
FEREMBACH D., SCHWIDETKZY I. and STLOUKAL M. 1979.

Empfehlungen für die Alters-und Geschlechtsdiagnose am Skelett. Homo 30/2: 1-32.

PEREMBACH, D., SCHWIDETZKY I. and STLOUKAL M. 1980.

Rekommondation for Age and Sex Diagnoses of Skeletons.J.Hum.Evol. 9: 517-549.

HOŠOVSKI E. andMIKIĆ Ž. 1995.

Paleopatologija čoveka. Narodni muzej. Užice.

KRONFELD R. 1954.

Development and Classification of the Human Deciduous and Permanent Dentation. Wenner Gren Pound.Anthrop.Res., New York, 2-11.

\section{LOVRINČEVIĆ A. and MIKIĆ Ž. 1989.}

Atlas of osteopathologic changes of the hystorical Yugoslav populations. Svjetlost. Sarajevo.

MARTIN R. and SALLER K. 1957

Lehrbuch der Anthropologie in systematischer Darstellung. Bd. 1. Stuttgart.

MIKIĆ Ž. 1988.

Prilog antropološkoj strukturi stanovništva Srbije. Etnoantropološki problemi - monografije knjiga 4, Beograd.

NEMESKERI J. 1970.

History of Human Life Span and Mortality. Akademiai Kiado. Budapest.

\section{STEINBOCH G.T. 1976.}

Paleopathological Diagnoses and Interpretations. Bone Diseases in Ancient Human Populations. Springfield: Charles C. Thomas.

\section{STUART - MACADAM P. 1985.}

Porotic hyperostosis: Representative of a childhood condition. Am. J. Phjs. Anthrop. 66: 391-298. 
WOLF - HEIDEGGER G. 1954.

Atlas der systematischen Anatomie des Menschen. Bd. 1. Basel - New York.

\section{REZIME}

SREDNJOVEKOVNE NEKROPOLE PORED ZAVOJSKOG JEZERA KOD PIROTA - PALEODEMOGRAFSKA I PALEOPATOLOŠKA ANALIZA

KLJUČNE REČI: BIOFIZIČKA ANTROPOLOGIJA, ARHEOLOGIJA, POLNA PRIPADNOST, INDIVIDUALNA STAROST, DUŽINA ŽIVOTA, PALEODEMOGRAFIJA, PALEOPATOlogiJa, PALEO-DEMOgRafSKa REKONSTRUKCIJA, PALEOPATOLOŠKA INTERPRETACIJA.

Pored manastira Svetog Nikole tokom arheoloških iskopavanja 1988. godine otkriveno je 28 skeleta. Pored crkve Svetog Vaznesenja iste godine otkriveno je 157 individualnih skeleta. U sklopu njihove antropološke obrade obavljena je paleodemografska, kao i paleo-patološka analiza. Dobijeni rezultati su vrlo indikativni za srednjovekovni period, konkretno za nekropole vezane za sakralne objekte nasuprot onim pored urbanih celina, a njihova prezentacija čini integralni deo ovog interdisciplinarnog priloga. 